\title{
Anomalous Branching Pattern of Lateral Cord of Brachial Plexus
}

\author{
Padrón de Ramos Anómalos del Fascículo Lateral del Plexo Braquial
}

"Srijit Das \& *"Shipra Paul

DAS, S. \& PAUL, S. Anomalous branching pattern of lateral cord of brachial plexus. Int. J. Morphol., 23(4):289-292, 2005.

SUMMARY: During routine dissection, an unusual formation of median nerve was detected in the right upper limb of a 55 year old male cadaver. The median nerve had an additional contribution from lateral cord. The two branches of the lateral cord designated as upper and the lower branches were observed at different levels. The upper branch was in close contact with the third part of the axillary artery and it crossed the vessel anteriorly to unite with a branch of the medial cord to form the median nerve. The median nerve thus formed was related medially to the axillary artery (instead of the normal position of being anterolateral). The median nerve descended below and was joined by an additional lower branch from the lateral cord. Interestingly, the ulnar nerve which arose from the medial cord, descended below and was joined within its fascial sheath by the medial cutaneous nerve of the forearm

The presence of such an additional branch from the lateral cord contributing to the formation of median nerve and its unusual relation of being medial to the axillary artery may be of immense clinical interest to neurologists diagnosing nerve lesions and surgeons who are exposed to the topographical anatomy of the neural structures during radical neck dissection. The additional branch of the lateral cord may compress upon the axillary artery to cause vascular insufficiency.

KEY WORDS: Lateral cord; Brachial plexus; Median nerve; Anatomical variation.

\section{INTRODUCTION}

As per classical anatomy text book description, the median nerve is formed by terminal branch of the lateral and the medial cord of the brachial plexus (Standring, 2005). The two roots from the lateral $(\mathrm{C} 5,6,7)$ and medial $(\mathrm{C} 8, \mathrm{~T} 1)$ cords embrace the third part of the brachial artery to unite anterior and lateral to it (Standring).

The present study describes a case of median nerve having two roots from the lateral cord and one from the medial cord. The formation of the median nerve related medial to the axillary artery, is a rare finding. Two roots from the lateral cord contributing to the formation of median nerve has been reported twice in the past (Sargon, et al., 1995: Saeed et al., 2003) but in our study in addition to the above findings, it was associated with abnormal position in relation to third part of axillary artery. There are few reports of the medial cutaneous nerve of the forearm joining the ulnar nerve within a common fascial sheath.
Often the variations in the formation of median nerve cannot be detected as they are only incidental findings during routine autopsy or cadaveric dissection. A variation as seen in the present study may be of academic interest to the neurologist in diagnosing nerve lesion. Anatomical knowledge of such variations are also important for surgeons during radical neck dissection surgery to check any inadvertent injury.

\section{CASE REPORT}

During routine dissection. an anomalous formation of median nerve was detected in the right upper limb of a 55 year old male cadaver. The branches of the lateral and the medial cord of brachial plexus were dissected carefully, its course were noted and appropriate photographs were taken (Fig.1).

\footnotetext{
* Associate Professor, Department of Anatomy, Maulana Azad Medical College, New Delhi-110002, India.
}

** Director Professor, Department of Anatomy, Maulana Azad Medical College, New Delhi-110002, India. 
On the right side we detected four branches from the lateral cord .The branches were musculocutaneous nerve (Fig.1 'c'), lateral pectoral nerve and the two branches which contributed to the formation of median nerve. The two branches from the lateral cord (Fig.1 'a') were found to be at different levels and were designated as upper ( Fig.1, single arrow) and the lower (Fig.1 double arrows) branches. The upper branch was short and thin and united with the medial root of the median nerve (Fig.1 'b') coming from the medial cord, anterior to the axillary artery to form the median nerve. The median nerve thus formed (Fig.1 'e') was related medially to the axillary artery (Fig.1 'h') which is a rare anomaly. The second branch i.e lower branch from the lateral cord, was given off at about $5 \mathrm{~cm}$ below the upper branch. The lower branch was longer and thicker than the upper one and joined the median nerve about $7.5 \mathrm{~cm}$ distal to its formation. The present study also showed the ulnar nerve (Fig.1 'f') accompanying the medial cutaneous branch of the forearm (Fig.1 ' $\mathrm{g}$ ') in a common fascial sheath (Fig.1 arrowhead).
The left upper limb showed normal branching pattern of the brachial plexus.

\section{DISCUSSION}

Previous studies reporting additional branch from the lateral cord in the formation of median nerve, have been found to be associated with anomalous communication between musculocutaneous nerve and the median nerve (Beheiry, 2004; Uzun et al., 2001: Sargon et al.; Saeed et al.) but in our study, no such communication was observed. An interesting finding which was observed in the present case was the relationship of the median nerve to the axillary artery. Normally the medial root of the median nerve crosses the axillary artery to unite with the lateral root to form the median nerve which is anterior or lateral to the axillary artery (Standring) but in our study the lateral (i.e upper branch) was crossing the axillary artery anteriorly and joining the medial root to form median nerve, medial to the artery.

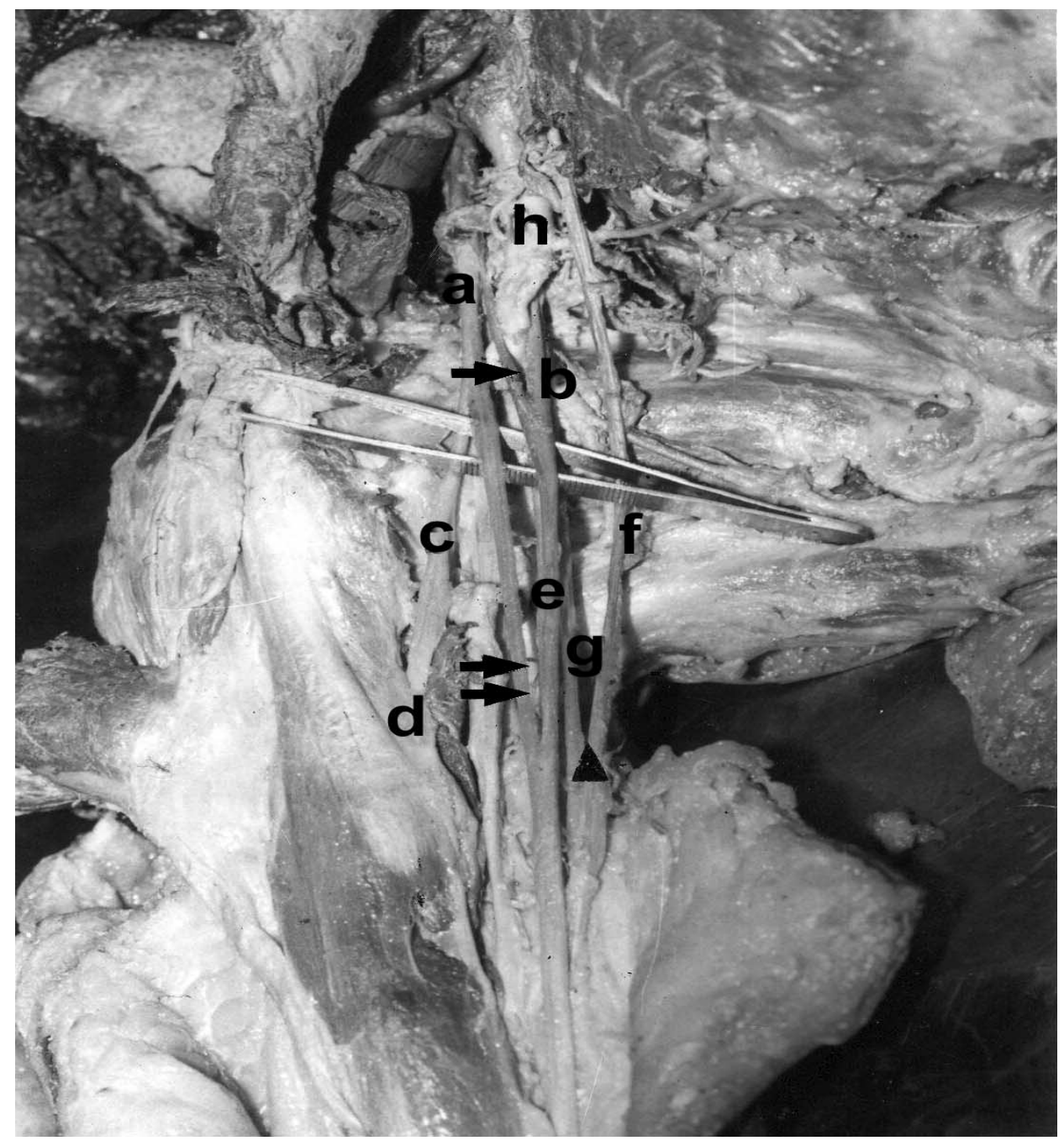

Fig. 1. Photograph of dissected specimen of right axilla showing:

a. Lateral cord of brachial plexus.

b. Medial root of median nerve. c. Musculocutaneous nerve.

d. Coracobrachialis muscle.

e. Median nerve.

f. Ulnar nerve.

g. Medial cutaneous nerve of forearm.

h. Axillary artery.

Single arrow: Upper branch from lateral cord.

Double arrows: Lower branch from lateral cord.

Arrowhead (^): Medial cutaneous nerve of forearm accompanying the ulnar nerve in a common fascial sheath. 
Past studies on fetuses had reported the variations of the brachial plexus to be more common in females and on the right side (Uysal et al., 2003). The present anomaly was also noted on the right side with the left being absolutely normal, thus conforming to the views of earlier author.

Anomalous branches of lateral cord crossing the artery anteriorly may cause compression symptoms producing ischemia. Such variations are likely to confuse the operating surgeons who usually operate in this region with the standard anatomical knowledge.

Embryological reasons of such anomalous branching pattern may be due to the role of random factors influencing the mechanism of formation of limb muscles and peripheral nerves (Saeed et al.). Past research study has also described any communication between two nerves as a result of neurobiotaxis occurring during fetal development (Saeed et al.).

The ulnar nerve in the present case had its usual origin from the medial cord, but the joining of the medial cutaneous nerve of the forearm within the common fascial sheath may also be of great clinical significance.

Past research studies have reported the fact that variant nerve sharing abnormal origin, course and distribution are more to accidental injuries and entrapment neuropathies (Roberts, 1992). During surgical procedures of the axilla and the shoulder, a surgeon is exposed to the topographical anatomy of the neural structures and awareness of such variations may be of immense clinical help. Knowledge of such anomalies are also important during treatment of fractures. Better understanding and correct interpretation of clinical neurophysiology can only be possible with prior academic knowledge ( Saeed et al.).

It is a known fact that normal and anomalous positions of the arteries and the veins may be determined preoperatively by angiographic studies, but in case of nerves it is not feasible to detect such an anomaly. It is only at the time of surgery that the surgeon is exposed to such variations. We as anatomists opine that prior anatomical knowledge of such anomalies may be of great help to neurologists, traumatologists and surgeons.

DAS, S. \& PAUL, S. Padrón de ramos anómalos del fascículo lateral del plexo braquial. Int. J. Morphol., 23(4):289-292, 2005.

RESUMEN: Durante una disección de rutina fue encontrada una formación inusual del nervio mediano en el miembro superior derecho, de un inividuo de sexo masculino, de 55 años de edad. El nervio mediano tenía una contribución adicional del facículo lateral. Los dos ramos del fascículo lateral, designados como ramos superior e inferior, fueron observados a diferentes niveles. El ramo superior tuvo un estrecho contacto con la tercera parte de la arteria axilar y cruzaba la vena axilar anteriormente para unirse con un ramo del fascículo medial y formar el nervio mediano. El nervio mediano así formado estaba relacionado medialmente con la arteria axilar (en vez de su posición normal de situación anterolateral). El nervio mediano se dirigía hacia bajo y se unía con un ramo inferior adicional del fascículo lateral. El nervio ulnar, que se originaba del fascículo medial, descendía posterior y se unía en la vaina fascial con el nervio cutáneo medial del antebrazo.

La presencia de un ramo adicional del fascículo lateral contribuyendo a la formación del nervio mediano y su inusual relación con la arteria axilar, tiene un interés clínico para los neurólogos, quienes diagnostican lesiones nerviosas, y cirujanos que están expuestos a encontrar variaciones de estructuras nerviosas durante disecciones radicales de cuello. El ramo adicional del fascículo lateral puede comprimir la arteria axilar y causar insuficiencia vascular.

PALABRAS CLAVE: Fascículo lateral; Plexo braquial; Nervio mediano; Variación anatómica.

\section{REFERENCES}

Beheiry, E. E. Anatomical variations of the median nerve distribution and communication in the arm. Folia Morphologica, 63(3):313-8, 2004.

Roberts, W. H. Anomalous course of the median nerve medial to the trochlea and anterior to the medial epicondyle of the humerus. Ann. Anat., 174(4):309-11, 1992.
Saeed, M. \& Rufai, A. A. Median and musculocutaneous nerves: variant formation and distribution. Clin. Anat., 16 (5): 453-7, 2003.

Sargon, M. F.; Uslu, S. S. ; Celik, H. H. \& Aksit, D. A variation of the median nerve at the level of brachial plexus. Bull. Assoc. Anat., 79(296):25-6, 1995. 
DAS, S. \& PAUL, S.

Standring S. Gray's Anatomy. 39th ed. Churchill Livingstone Elsevier, New York, 2005.

Uysal, II. ; Seker, M.; Karabulut, A. K.; Buyukmumcu, M. \& Ziylan, T. Brachial plexus variations in human fetuses. Neurosurgery, 53 (3):676-84, 2003.

Uzun, A. \& Seelig, L. L. Jr. A variation in the formation of the median nerve; communicating branch between the musculocutaneous and median nerves in man. Folia Morphologica, 60(2):99-101, 2001.
Correspondence to: Dr. Shipra Paul, $\mathcal{M B B B S}, \mathcal{M D}$ Director Professor of Anatomy

$\mathcal{D}-I I / \mathcal{A}-75$, NanakPura

Moti Bagh-South

New Delfi-110021

$I \mathcal{N}(\mathcal{D} I \mathcal{A}$

Tel: 91-011-26119751

E-mail:drshipra14@yahoo.com

Received : 18-06-2005

Accepted : 15-09-2005 